\title{
Immunosuppressant therapy and bone loss in ligature-induced periodontitis - a study in rats
}

\section{Terapia imunossupressora e perda óssea em periodontite induzida por ligaduras - um estudo em ratos}

\author{
Patricia Furtado Gonçalves* \\ Getúlio da Rocha Nogueira Filho** \\ Enilson Antonio Sallum*** \\ Antonio Wilson Sallum**** \\ Francisco Humberto Nociti Junior*****
}

\begin{abstract}
Immunosuppressive agents have been recognized as a factor affecting the soft tissues of the periodontium. However, little is known about their effect on periodontitis progression. The aim of the present study was to investigate the influence of cyclosporin A (CsA) administration, associated or not with nifedipine, on the bone loss resulting from a ligature-induced periodontitis in rats. Twenty-four adult male Wistar rats were used. After anesthesia, the mandibular first molar was randomly assigned to receive the cotton ligature in the sulcular area while the contralateral tooth was left unligated. The animals were randomly assigned to one of the following treatments: Group A - saline solution; Group B - CsA (10 mg/kg); Group C - nifedipine (50 mg/kg); Group D - CsA (10 mg/kg) plus nifedipine (50 mg/kg). Forty-five days later, the animals were sacrificed and the specimens routinely processed for serial decalcified sections. Intergroup analysis did not reveal significant differences regarding the bone loss volume in the ligated teeth between the experimental treatments $(0.46 \pm 0.11,0.63 \pm 0.32,0.53 \pm 0.14,0.50 \pm 0.18$, for groups $\mathrm{A}, \mathrm{B}, \mathrm{C}$ and $\mathrm{D}$, respectively $\mathrm{p}>0.05)$. However, intragroup analysis showed a greater bone loss volume in the ligated teeth than in the unligated ones ( $\mathrm{p}<0.05)$. Within the limits of the present study, the conclusion was that the administration of CsA, associated or not with nifedipine, may not influence bone loss in ligature-induced periodontitis in rats.
\end{abstract}

DESCRIPTORS: Bone resorption; Periodontitis; Immunosuppression.

RESUMO: O uso de agentes imunossupressores tem sido reconhecido como um fator que afeta os tecidos moles do periodonto. Entretanto, pouco se sabe sobre o seu efeito na progressão da periodontite. O objetivo do presente estudo foi investigar a influência da ciclosporina ( $\mathrm{CsA}$ ), associada ou não à nifedipina, na perda óssea resultante da periodontite induzida por ligaduras em ratos. Vinte e quatro ratos Wistar machos, adultos, foram incluídos no estudo. Após anestesia, foram colocadas ligaduras de fio de algodão ao redor do primeiro molar inferior direito ou esquerdo, aleatoriamente escolhido. O dente contralateral foi deixado sem ligadura. Os animais foram aleatoriamente escolhidos para receber um dos seguintes tratamentos: Grupo A - solução salina; Grupo B - CsA (10 mg/kg); Grupo C - nifedipina (50 mg/kg); Grupo D - CsA (10 mg/ kg) e nifedipina (50 mg/kg). Após 45 dias, os animais foram sacrificados para a análise histométrica. A análise intergrupos não revelou diferenças significativas quanto ao volume da perda óssea entre os diferentes tratamentos $(0,46 \pm 0,11 ; 0,63 \pm 0,32 ; 0,53 \pm 0,14 ; 0,50 \pm 0,18$, para os grupos $\mathrm{A}, \mathrm{B}, \mathrm{C}$ e D respectivamente $\mathrm{p}>0,05)$. Entretanto, a análise intragrupo mostrou um maior volume de perda óssea nos dentes com ligadura, quando comparados aos dentes sem ligadura $(\mathrm{p}<0,05)$. Dentro dos limites deste estudo, conclui-se que a administração de CsA, associada ou não à nifedipina, não influenciou a perda óssea alveolar na periodontite induzida por ligaduras em ratos.

DESCRITORES: Reabsorção óssea; Periodontite; Imunossupressão.

\section{INTRODUCTION}

The primary cause of periodontitis is the cumulative effect of the interaction between bacterial challenge and the immune and inflammatory system of the host. Risk factors for periodontitis include poor oral hygiene, age, genetic factors, dia- betes and smoking ${ }^{11}$. In addition, a deficient host immune response has been associated with a more aggressive type of periodontitis ${ }^{15}$. Thus, the effect of immunosuppressant agents on the periodontal tissues has been investigated ${ }^{19}$.

One of the most studied immunosuppressant agents is cyclosporin A (CsA), a fungal cyclic

${ }^{*}$ Doctorate student; ${ }^{* *} \mathrm{PhD} ;{ }^{* * *}$ Assistant Professor; ${ }^{* * * *}$ Chairman and Professor; ${ }^{* * * * *}$ Assistant Professor - Department of Prosthodontics and Periodontics, division of Periodontics, School of Dentistry at Piracicaba, State University of Campinas. 
Gonçalves PT, Nogueira Filho G da R, Sallum EA, Salum AW, Nociti Junior FH. Immunosuppressant therapy and bone loss in ligature-induced periodontitis - a study in rats. Pesqui Odontol Bras 2003;17(1):46-50.

undecapeptide that has shown promise in the treatment of autoimmune disorders such as psoriasis, atopic dermatitis, rheumatoid arthritis and uveitis $^{12}$. Nevertheless, despite its many therapeutic uses and its profound effect on the prevention of organ rejection, side effects are not infrequent. Post-transplantation osteoporosis is a wellrecognized phenomenon ${ }^{10}$, as well as gingival overgrowth, bone formation and resorption ${ }^{3,8,13,21,24}$. Besides bone metabolism disorders, CsA administration has been associated with nephrotoxicity, and nifedipine, a calcium channel blocker, has been reported to protect against cyclosporin-induced toxicity ${ }^{17}$. Similarly to CsA, nifedipine has demonstrated a potential effect upon bone metabolism $^{5,22}$ and gingival overgrowth ${ }^{25}$.

Whether the association of CsA and nifedipine may increase the risk of periodontitis in non-risk individuals, it is not known. Therefore, the present study was proposed in order to investigate the influence of CsA administration on the bone loss resulting from a ligature-induced periodontitis in rats. In addition, the effect of nifedipine associated or not with CsA on such a process was also assessed.

\section{MATERIALS AND METHODS}

Twenty-four male Wistar rats (300-400 g) were used in the entire study. The animals were kept in plastic cages with access to food and water ad libitum. The State University of Campinas Institutional Animal Care and Use Committee approved the protocol.

General anesthesia was obtained by intramuscular administration of ketamine $(0.5 \mathrm{ml} / \mathrm{kg})$. One of the mandibular first molars of each animal was randomly assigned to receive the cotton ligature in a submarginal position to induce experimental periodontitis. The contralateral tooth was left unligated to serve as a control. The animals were randomly assigned to one of the following four treatment groups ( 6 animals per group), including daily subcutaneous injections:

- Group A - physiological saline;

- Group B - CsA (10 mg/kg) (Sandimmun ${ }^{\circledR}$, Novartis Pharma AG, Basel, Switzerland);

- Group C - nifedipine (50 mg/kg) (Sigma, St. Louis, MO, USA);

- Group D - CsA (10 mg/kg) plus nifedipine (50 mg/kg).

Forty-five days after the surgery, the animals were sacrificed by a lethal dose of ketamine, and their jaws were removed and fixed in 4\% neutral formalin for $48 \mathrm{~h}$. The specimens were demineralized in a solution of equal parts of $50 \%$ formic acid and $20 \%$ sodium citrate for 45 days. Paraffin serial sections $(6 \mu \mathrm{m})$ were obtained in a mesiodistal direction and stained with hematoxylin and eosin. Using an image analysis system (Image-Pro ${ }^{\circledR}, \mathrm{Me}-$ dia Cybernetics, Silver Spring, MD, USA), the volume of bone loss in the furcation region was histometrically determined. Measurements were averaged to allow intergroup and intragroup analyses, using the one-way analysis of variance $($ ANOVA) $($ alpha $=0.05)$. Pairwise multiple comparisons were carried out by Tukey's test (alpha $=0.05)$ in the cases where the ANOVA test showed significant differences. In addition, the paired $t$-test (alpha $=0.05$ ) was used for intragroup comparisons of interradicular bone loss volume between ligated and unligated teeth.

\section{RESULTS}

\section{Clinical observations}

Clinically, on the day of the sacrifice, it was noted that the animals from group B, C and D, i.e., the animals which received CsA and/or nifedipine, presented a greater gingival volume than the animals from group A (control group). Visually, when comparing ligated and unligated teeth in the same animals, the gingival volume was more significant for the ligated teeth.

\section{Histometric results}

Intragroup analysis revealed a statistically significant difference in the volume of bone loss $(p<0.05)$ between unligated and ligated teeth for all experimental groups, i.e., the cotton ligatures around the teeth were able to promote periodontitis (Table 1). Nevertheless, intergroup analysis did not show significant differences between the test groups ( $p>0.05)$ regarding the volume of bone loss around the ligated teeth (Table 1). Figures 1A to 1D illustrate the histological aspects of the mesiodistal sections of the ligated teeth, for each group. In all of them, it is possible to identify coronal dentin, pulp tissue, root dentin (mesial and distal roots), bone and periodontal ligament. The interradicular region shows a great area of connective tissue, resulting from bone loss under the furcation. Note the irregular bone surface in this region. 
Gonçalves PT, Nogueira Filho G da R, Sallum EA, Salum AW, Nociti Junior FH. Immunosuppressant therapy and bone loss in ligature-induced periodontitis - a study in rats. Pesqui Odontol Bras 2003;17(1):46-50.

TABLE 1 - Mean \pm standard deviation of the bone loss volume $\left(\mathrm{mm}^{3}\right)$ around unligated and ligated teeth, according to each group.

\begin{tabular}{c|c|c|c|c}
\hline \hline Teeth & Group A & Group B & Group C & Group D \\
\hline Unligated & $0.23 \pm 0.08 \mathrm{aA}$ & $0.23 \pm 0.08 \mathrm{aA}$ & $0.20 \pm 0.04 \mathrm{aA}$ & $0.24 \pm 0.07 \mathrm{aA}$ \\
\hline Ligated & $0.46 \pm 0.11 \mathrm{bB}$ & $0.63 \pm 0.32 \mathrm{bB}$ & $0.53 \pm 0.14 \mathrm{bB}$ & $0.50 \pm 0.18 \mathrm{bB}$ \\
\hline \hline
\end{tabular}

Capital letters should be considered in lines (intergroup analysis: one-way analysis of variance - ANOVA -, $p>0.05$ ) and lowercase letters in columns (intragroup analysis: paired $t$-test, $p<0.05$ ). Means followed by different letters differ statistically (alpha $=0.05)$.
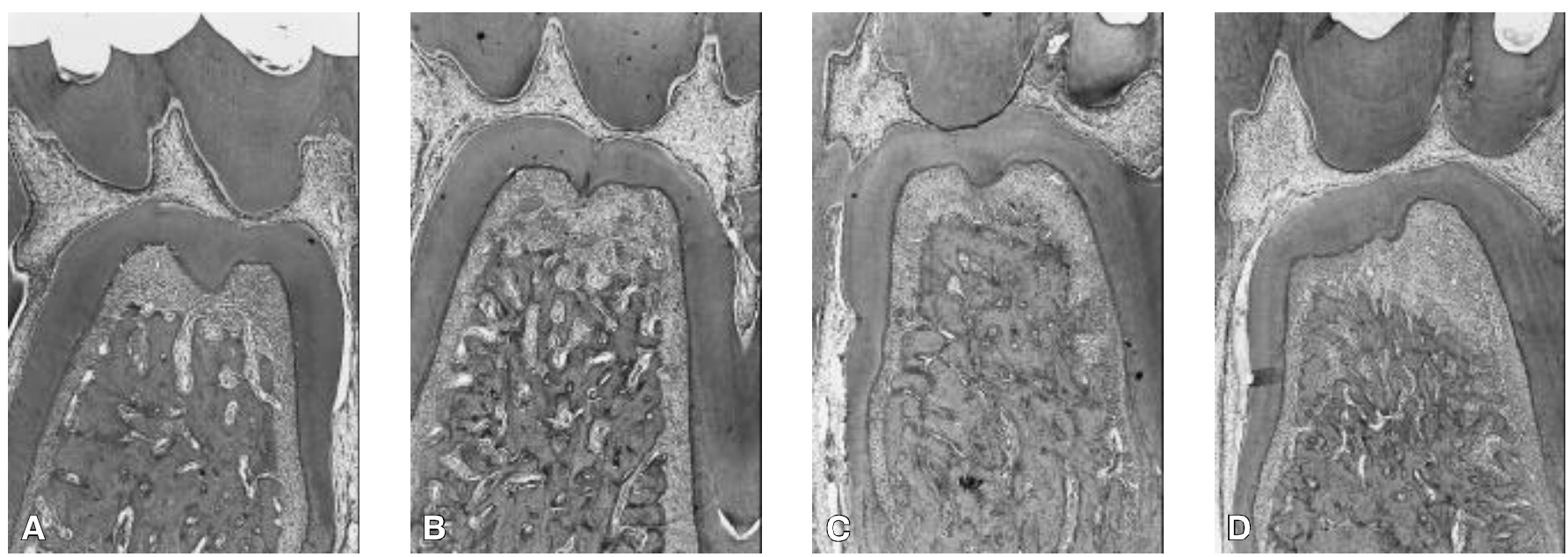

FIGURE 1 - Photomicrography illustrating bone loss in the furcation region of a ligated tooth. A, B, C and $\mathbf{D}$ illustrate Groups A, B, C and D, respectively (H. E., 12.5 X). A: Control group. B: Cyclosporin A group. C: Nifedipine group. D: Cyclosporin A + Nifedipine group.

\section{DISCUSSION}

Immunosuppression is an important therapeutic regimen for several diseases ${ }^{4}$, including lifelong medication with substances like CsA in order to counteract rejection of transplanted tissues. The effects of CsA therapy on soft tissues of the periodontium have been extensively investigated in $v i$ $\operatorname{tro}^{1,23}$ and in vivo ${ }^{26,27}$. Recently, the significance of CsA on alveolar bone has received some attention. Increased bone remodeling and trabecular bone loss have been observed in CsA-exposed animals ${ }^{7,18,24}$. Increased osteoblastic and decreased osteoclastic activity in patients undergoing CsA treatment has been reported ${ }^{29}$. Although some attention has been paid to the influence of CsA on alveolar bone, little is known about this interaction in the presence of a local irritant such as dental biofilm.

The results of the present study did not reveal significant differences among the experimental groups regarding the volume of bone loss resulting from the ligature-induced periodontitis in rats. This means that daily CsA administration, associated or not with nifedipine, did not result in a more severe bone loss in the furcation of the teeth. The findings of the present study seem to be in agreement with those of previous studies. Although some have described the importance of T-cell mediated hypersensitivity in human gingivitis and periodontitis ${ }^{16}$, this concept has been challenged by negative findings in humans ${ }^{14}$ and by animal studies $^{20}$. Guggenheim et al. ${ }^{9}$ (1981) investigated whether T-suppression with CsA had an effect on the establishment and progression of the disease in rats monoassociated with Actinomyces viscosus. They concluded that periodontal disease seems to be the result of a multitude of pathomechanisms and is not strictly correlated with T-cell dependent hypersensitivity. Cox et al. ${ }^{2}$ (1987) showed that ligature-induced periodontitis bone loss was less pronounced in rats treated with CsA, when compared to that of control non-medicated animals. Fischer, Klinge $^{6}$ (1994) evaluated, clinically and histo- 
Gonçalves PT, Nogueira Filho G da R, Sallum EA, Salum AW, Nociti Junior FH. Immunosuppressant therapy and bone loss in ligature-induced periodontitis - a study in rats. Pesqui Odontol Bras 2003;17(1):46-50.

logically, the effect of CsA on the progression of the periodontal breakdown in domestic ferrets, using the ligature-induced periodontitis model. They observed a tendency of more bone loss in the experimental medicated animals as compared to the values of non-medicated ones. However, the differences were not statistically significant. Therefore, as mentioned by Guggenheim et al. ${ }^{9}$ (1981), it appears that the clinical aspect of the periodontal disease may be the result of independent mechanisms, i.e., even blocking such an important element, all other elements may not be significantly affected. Generally speaking, a variety of host defense disorders may lead to destruction of the periodontal attachment apparatus and eventually premature exfoliation of primary and/or permanent teeth. However, most of the studies, including the present investigation, were not able to histologically illustrate such a clinical figure, by affecting the T-cell response to the local irritants. Therefore, further studies on the etiopathogenesis of the periodontal lesions, regarding the role of the host immune response, are justified.

The subcutaneous route, which was used in this study, has been suggested as the route of choice $^{28}$ to provide more consistent cycles of CsA availability than any other route. Blood levels of CsA between 100 and $400 \mathrm{ng} / \mathrm{ml}$ have been shown to be sufficient to promote immunosuppression in

\section{REFERENCES}

1. Bartold PM. Regulation of human gingival fibroblast growth and synthetic activity by cyclosporine-A in vitro. $\mathrm{J}$ Periodontal Res 1989;24:314-21.

2. Cox DS, Williams-Miller C, Nadib T. Role of interleukin-2 in periodontal bone loss in the ligated rats [abstract]. J Periodontol 1987;58:130.

3. Cvetkovic M, Mann GN, Romero DF, Liang XG, Ma Y, Jee $\mathrm{WS}$, et al. The deleterious effects of long-term cyclosporine A, cyclosporine G, and FK506 on bone mineral metabolism in vivo. Transplantation 1994;27;57:1231-7.

4. Daley TD, Wysocki GP. Cyclosporine therapy. Its significance to the periodontist. J Periodontol 1984;55:708-12.

5. Duriez J, Flautre B, Blary MC, Hardouin P. Effects of the calcium channel blocker nifedipine on epiphyseal growth plate and bone turnover: a study in rabbit. Calcif Tissue Int 1993;52:120-4.

6. Fischer RG, Klinge B. Clinical and histological evaluation of ligature-induced periodontal breakdown in domestic ferrets immunosuppressed by Cyclosporin-A. J Clin Periodontol 1994;21:240-9. humans. Likewise, in animals, blood levels between 100 and $400 \mathrm{ng} / \mathrm{ml}$ have been considered to be effective ${ }^{28}$. The dosage of CsA used in the present study $(10 \mathrm{mg} / \mathrm{kg}, \mathrm{SQ})$ has been shown to produce sufficient blood levels to induce immunosuppression in rodents ${ }^{6}$.

Calcium channel blockers (CCBs) such as nifedipine are widely used in cardiovascular therapy and recently have been utilized for the control of cyclosporin-induced toxicity ${ }^{17}$. However, the effect of CCBs appears not to be limited to the cardiovascular system and may involve calcium metabolism as well ${ }^{5,22}$. In the present study, nifedipine groups showed rates of periodontitis progression similar to that of other groups. Since this is the first study to investigate whether nifedipine could influence bone loss in ligature-induced periodontitis, our results must be analysed with caution and further studies should be considered.

\section{CONCLUSION}

The data of the present study suggest that the administration of CsA, associated or not with nifedipine, may not influence bone loss in ligature-induced periodontitis in rats.

\section{ACKNOWLEDGMENT}

The authors greatly appreciated the assistance of Rodrigo Borges Fonseca, DDS, for administering the drugs to the animals.

7. Fu E, Hsieh YD, Nieh S, Wikesjo UM, Liu D. Effects of cyclosporin-A on alveolar bone: an experimental study in the rat. J Periodontol 1999;70:189-94.

8. Fu E, Nieh S, Wikesjo UM, Lin FG, Shen EC. Gingival overgrowth and dental alveolar alterations: possible mechanisms of cyclosporin-induced tooth migration. An experimental study in the rat. J Periodontol 1997;68:1231-6.

9. Guggenheim B, Gaegauf-Zollinger R, Hefti A, Burckhardt JJ. The effect of cyclosporin A on periodontal disease in rats monoassociated with Actinomyces viscosus Ny 1 . J Periodontal Res 1981;16:26-38.

10. Guo CY, Johnson A, Locke TJ, Eastell R. Mechanisms of bone loss after cardiac transplantation. Bone 1998; 22:267-71.

11. Johnson NW, Griffiths GS, Wilton JM, Maiden MF, Curtis MA, Gillett IR, et al. Detection of high-risk groups and individuals for periodontal diseases. Evidence for the existence of high-risk groups and approaches to their detection. J Clin Periodontol 1988;15:276-82.

12. Kahan BD. Cyclosporine. N Engl J Med 1989;21; 321:1725-38. 
Gonçalves PT, Nogueira Filho G da R, Sallum EA, Salum AW, Nociti Junior FH. Immunosuppressant therapy and bone loss in ligature-induced periodontitis - a study in rats. Pesqui Odontol Bras 2003;17(1):46-50.

13. Kawana K, Takahashi M, Kushida K, Hoshino H, Sakata S, Inoue $\mathrm{T}$. The effect of cyclosporin A administration on bone metabolism in the rat evaluated by biochemical markers. J Endocrinol Invest 1996;19:499-504.

14. Kiger RD, Wright WH, Creamer HR. The significance of lymphocyte transformation responses to various microbial stimulants. J Periodontol 1974;45:780-5 .

15. Kinane DF, Johnston FA, Evans CW. Depressed helper-to-suppressor T-cell ratios in early-onset forms of periodontal disease. J Periodontal Res 1989;24:161-4.

16. Lehner T, Wilton JM, Challacombe SJ, Ivanyi L. Sequential cell-mediated immune responses in experimental gingivitis in man. Clin Exp Immunol 1974;16:481-92.

17. Liesveld J, Duerst R, Rapoport A, Constine L, Abboud C, Packman $\mathrm{C}$, et al. Continuous infusion cyclosporine and nifedipine to day +100 with short methotrexate and steroids as GVHD prophylaxis in unrelated donor transplants. Bone Marrow Transplant 1999;24:511-6.

18. Movsowitz C, Epstein S, Fallon M, Ismail F, Thomas S. Cyclosporin-A in vivo produces severe osteopenia in rats: effect of dose and duration of administration. Endocrinology 1988;123:2571-7.

19. Nieh S, Fu E, Chang HL, Wang SL, Wikesjo UM. Histopathologic alterations of periodontium in cyclosporin-treated rats. Is the periodontium a target tissue for the drug? J Clin Periodontol 1996;23:730-6.

20. Nobreus N, Attstrom R, Egelberg J. Effect of anti-thymocyte serum on the development of gingivitis in dogs. J Periodontal Res 1974;9:227-35.
21. Orcel P, Denne MA, de Vernejoul MC. Cyclosporin-A in vitro decreases bone resorption, osteoclast formation, and the fusion of cells of the monocyte-macrophage lineage. Endocrinology 1991;128:1638-46.

22. Ritchie CK, Maercklein PB, Fitzpatrick LA. Direct effect of calcium channel antagonists on osteoclast function: alterations in bone resorption and intracellular calcium concentrations. Endocrinology 1994;135:996-1003.

23. Schincaglia GP, Forniti F, Cavallini R, Piva R, Calura G, del Senno L. Cyclosporin-A increases type I procollagen production and mRNA level in human gingival fibroblasts in vitro. J Oral Pathol Med 1992;21:181-5.

24. Schlosberg M, Movsowitz C, Epstein S, Ismail F, Fallon MD, Thomas S. The effect of cyclosporin A administration and its withdrawal on bone mineral metabolism in the rat. Endocrinology 1989;124:2179-84.

25. Seymour RA. Calcium channel blockers and gingival overgrowth. Br Dent J 1991;25;170:376-9.

26. Seymour RA, Smith DG, Rogers SR. The comparative effects of azathioprine and cyclosporin on some gingival health parameters of renal transplant patients. J Clin Periodontol 1987; 14:610-3.

27. Somacarrera ML, Hernandez G, Acero J, Moskow BS. Localization of gingival overgrowth in heart transplant patients undergoing cyclosporin therapy. J Periodontol 1994; 65:666-70.

28. Wassef R, Cohen Z, Langer B. Pharmacokinetic profiles of cyclosporine in rats. Influence of route of administration and dosage. Transplantation 1985;40:489-93.

29. Wilmink JM, Bras J, Surachno S, van Heyst JL, van der Horst JM. Bone repair in cyclosporin-treated renal transplant patient. Transplant Proc 1989;21:1492-4.

Recebido para publicação em 22/05/02

Enviado para reformulação em 29/11/02

Aceito para publicação em 18/12/02 